\title{
The effect of proper oral hygiene habits on oral cavity health
}

\section{Wpływ właściwych zachowań dotyczących higieny jamy ustnej na jej zdrowie}

\author{
Aleksandra Kalandyk-Konstanty 1, A, B, D-E, Janusz Konstanty-Kalandyk', A, D, Joanna Zarzecka1, A, F, Jerzy Sadowski2, A, F, Rafał Drwila 3, E, \\ Krzysztof Bartus', C, E, Tomasz Darocha ${ }^{3, C}$, Jacek Piątek2, E, Bogusław Kapelak2, E, F \\ 1 Department of Conservative Dentistry and Endodontics, Jagiellonian University Collegium Medicum, Kraków, Poland \\ 2 Department of Cardiovascular Surgery and Transplantology, John Paul II Hospital, Jagiellonian University Collegium Medicum, Kraków, Poland \\ 3 Department of Anesthesiology and Intensive Care, John Paul II Hospital, Kraków, Poland \\ A - research concept and design; B - collection and/or assembly of data; $\mathrm{C}$ - data analysis and interpretation; \\ $D$ - writing the article; $E$ - critical revision of the article; $F$ - final approval of article
}

\begin{abstract}
Address for correspondence
Aleksandra Kalandyk-Konstanty

E-mail: aleksandra.kalandykkonstanty@op.pl

Funding sources

none declared

Conflict of interest

none declared

\section{Acknowledgements}

Project was co-financed by the National Science Centre for Research and Development. Project title: „Dental examination in patients selected for cardiac surgery - PREVENT". Project number: 6 ZR 92008 C/07133.
\end{abstract}

Received on November 27, 2016

Revised on December 18, 2016

Accepted on January 12, 2017

\begin{abstract}
Background. The condition of oral health among Polish patients is poor. The number of edentulous patients or those requiring major surgical procedures is growing. Improper health habits may affect oral hygiene.
\end{abstract}

Objectives. The objective of the study was to evaluate the effect of tooth brushing and visiting dentist to see if there are any pathological changes in the oral cavity.

Material and methods. Hundred and sixty-three patients underwent dental examinations comprised of the following elements: intraoral and extraoral examination, radiographs and a questionnaire about daily habits.

Results. Patients brushing teeth 3 times a day were mostly put in class $0-2$ CPITN. API $>75 \%$ occurred most frequently in irregular teeth brushing $(85 \%, p=0.07)$. CPITN index from 0 to 2 was found mostly in patients attending the dentist once a year or more frequently (80 vs 64 vs $50 \%, p=0.014$ ). API index $>70 \%$ was significantly more common in patients visiting dentist irregularly (69 vs 55 vs $29 \%$, $p<0.001)$. Most residual roots were also reported in patients who do not regularly brush their teeth (33\%). Those patients have more frequent instances oral diseases requiring surgical treatment and suffer a greater risk of odontogenic inflammatory foci.

Conclusions. Irregular follow-up visits and irregular tooth brushing lead to the deterioration of oral health status and can enhance the risk of the necessity of surgical treatment.

Key words: oral hygiene, health habits, periodontal heaith

Słowa kluczowe: higiena jamy ustnej, nawyki higieniczne, zdrowie przyzębia

DOI

$10.17219 / \mathrm{dmp} / 68453$

Copyright

○ 2017 by Wroclaw Medical University

and Polish Dental Society

This is an article distributed under the terms of the

Creative Commons Attribution Non-Commercial License

(http://creativecommons.org/licenses/by-nc-nd/4.0/) 
Proper oral hygiene is an important element of maintaining proper health. Many researchers emphasize the connection between periodontal diseases and systemic diseases. ${ }^{1,2}$ Unfortunately, the condition of oral health among Polish patients is poor. Dental caries are still a major problem not only in Poland but also in many other countries. They concern a large number of adult patients. ${ }^{3-5}$ The prevalence of periodontal diseases is significantly different between countries, ${ }^{6-8}$ and they are still a major problem especially in older groups. ${ }^{3}$ Advanced periodontal disease, which can cause tooth loss is observed in 5-15\% of people 35-44 years old. ${ }^{9}$ Among European countries, the lowest percentages of edentulous (below 20\%) were found in Lithuania (14\%), Austria and Iceland (15\%) and highest 40\% in Finland (41\%), Slovakia (44\%) and Bosnia and Herzegovina (78\%). In Poland, we observe an increase in the proportion of edentulous people aged $35-44$ years from 1.6 to $3.8 \% .^{10}$ The proportion of edentulous people aged 65-74 years in our country has reached $41.6 \% .{ }^{11}$ The potential reason for this situation is very poor oral hygiene.

\section{Objectives}

Epidemiological studies indicate that the majority of older people in Poland, as well as in other European countries and in the United States do not have the proper habits that allow them to maintain proper oral hygiene. ${ }^{12-14}$

The aim of our study was to analyze the relationship between habits in maintaining proper oral hygiene and oral health.

\section{Material and methods}

The study included 163 patients scheduled for cardiac operations. Before the operation, patients underwent a dental examination comprised of the following elements: intraoral and extraoral examination and radiographs (the review of the pantomographic image). Patients also completed a questionnaire on their daily health habits for maintaining proper oral hygiene. The questionnaire focused on the frequency of tooth brushing and the number of visits to the dentists. The average age of patients in the study was 60 years. Thirty-four percent of patients were over 65 years. In this intraoral study we evaluated: Community Periodontal Index of Treatment Needs (CPITN), Approximal Plaque Index (API), the presence of gingival pocket above $6 \mathrm{~mm}$, indications for professional oral hygiene, indications for conservative, endodontic and surgical treatment.

In radiographic study we evaluated the presence of periapical lesions (OKW), the presence of residual roots, impacted teeth, vertical and horizontal alveolar bone at-
Table 1. Frequency of brushing teeth and the frequency of visits to the dentists

\begin{tabular}{|c|c|c|c|c|}
\hline \multicolumn{2}{|c|}{ Brushing teeth } & $\begin{array}{c}3 \text { times per day } \\
\text { or more often }\end{array}$ & $\begin{array}{l}1 \text { or } 2 \text { times } \\
\text { per day }\end{array}$ & Irregularly \\
\hline \multicolumn{2}{|c|}{ All group } & 12 & 84 & 4 \\
\hline \multirow{2}{*}{ Age } & $<65$ years & 14 & 82 & 4 \\
\hline & $>65$ years & 6 & 90 & 4 \\
\hline \multicolumn{2}{|c|}{$\begin{array}{l}\text { Control visits } \\
\text { to the dentist }\end{array}$} & $\begin{array}{l}\text { Once a year, or } \\
\text { more frequently }\end{array}$ & $\begin{array}{l}\text { Once every } \\
\text { 2-5 years }\end{array}$ & Irregularly \\
\hline \multicolumn{2}{|c|}{ All group } & 40 & 26 & 34 \\
\hline \multirow{2}{*}{ Age } & $<65$ years & 44 & 24 & 32 \\
\hline & $>65$ years & 33 & 31 & 36 \\
\hline
\end{tabular}

All data are presented in percentages.

rophy, the presence of caries and indications for primary and re-endodontic treatment and the indications for surgical treatment. On the basis of all the completed studies, the authors assessed the presence of potential foci of inflammation in the oral cavity.

Statistical analyses were performed using STATISTICA v. 10. Categorical data was compared by the $\chi^{2}$ test or the Fisher exact test if the expected number of observations in any cell was $<5$. Continuous data is presented as mean $\pm \mathrm{SD}$ or median interquartile range and was compared using the analysis of variance or Kruskal-Wallis test, as appropriate. Values of $\mathrm{p}<0.05$ were considered to be statistically significant and all p-values are 2 -sided.

\section{Results}

In the whole group, only $4 \%$ of patients do not brush teeth regularly. Most patients brush their teeth 1 or 2 times per day (84\%) (Table 1). Only $12 \%$ of respondents in the age below 65 years of age brush their teeth more than 2 times a day (14\%).

Sixty-six percent of respondents declare regular visits to the dentist. Most patients (40\%) go to the dentist once a year or more frequently. With age, the frequency of regular visits decreases and in patients above 65 years the frequency reaches the level of 33\% (Table 1).

We also compared the impact of tooth brushing frequency on oral hygiene. In the periodontal assessment we used the CPITN index (Community Periodontal Index of Treatment Needs). Patients brushing teeth 3 times a day were mostly in class $0-2(84 \%)$, while half of the patients

Table 2. CPITN depending on frequency of teeth brushing

\begin{tabular}{|c|c|c|c|}
\multirow{2}{*}{ CPITN } & \multicolumn{3}{|c|}{ The frequency of teeth brushing } \\
\cline { 2 - 4 } & $\begin{array}{c}3 \text { times or more } \\
\text { often a day }\end{array}$ & 1 or 2 times a day & not at all \\
\hline $0-2$ & 84 & 65 & 50 \\
$3-4$ & 16 & 35 & 50 \\
\hline
\end{tabular}

$p=0.24$. All data are presented in percentages 
Table 3. Effect of teeth brushing frequency on oral hygiene

\begin{tabular}{|c|c|c|c|c|}
\hline \multirow{2}{*}{ Variable } & \multicolumn{3}{|c|}{ The frequency of teeth brushing } & \multirow{2}{*}{ p-value } \\
\hline & 3 times or more often a day & 1 or 2 times a day & not at all & \\
\hline $\mathrm{API}>75$ & 32 & 49 & 85 & 0.07 \\
\hline The presence of inflammatory foci & 63 & 82 & 83 & 0.1 \\
\hline Periradicular lesions & 21 & 38 & 33 & 0.36 \\
\hline Gingival pockets > 6 mm & 21 & 43 & 50 & 0.15 \\
\hline Residual roots & 11 & 22 & 33 & 0.38 \\
\hline Professional hygienisation & 58 & 50 & 59 & 0.9 \\
\hline Conservative treatment & 16 & 41 & 50 & 0.094 \\
\hline Surgical treatment & 32 & 44 & 83 & 0.08 \\
\hline Endodontic treatment & 26 & 24 & 17 & 0.89 \\
\hline
\end{tabular}

All data are presented in percentages.

who have declared that they do not brush their teeth regularly were in a class CPITN 3-4 (Table 2).

We evaluated the status of other parameters of oral hygiene such as API (Approximal Plaque Index). API > 75\% occurred most frequently in patients who do not regularly brush their teeth $(85 \%, \mathrm{p}=0.07)$ (Table 3$)$. The difference in this parameter between the different groups was large and approached statistical significance. In this group, most patients had deep alveolar pockets above $6 \mathrm{~mm}(50 \%)$ and required professional oral hygiene procedures at dental office (59\%). Most residual roots were also reported in patients who do not regularly brush their teeth (33\%).

The lowest number of patients who experienced potential foci of inflammation was in the group that brush-

Table 4. CPITN depending on the frequency of dental control visits

\begin{tabular}{|c|c|c|c|}
\multirow{2}{*}{ CPITN } & \multicolumn{3}{|c|}{ The frequency of control visits to the dentist } \\
\cline { 2 - 4 } & once per year & $\begin{array}{c}\text { once every } \\
3-5 \text { years }\end{array}$ & it is not attending \\
\hline $0-2$ & 80 & 64 & 50 \\
$3-4$ & 20 & 36 & 50 \\
\hline
\end{tabular}

$p=0.014$. All data are presented in percentages.

Table 5. Effect of dental control visits frequency on oral hygiene

\begin{tabular}{|c|c|c|c|c|}
\hline \multirow{2}{*}{ Variable } & \multicolumn{3}{|c|}{ The frequency of control visits to the dentist } & \multirow{2}{*}{$p$-value } \\
\hline & once a year & once every $3-5$ years & it is not attending & \\
\hline $\mathrm{API}>75$ & 29 & 55 & 69 & $<0.001$ \\
\hline The presence of inflammatory foci & 77 & 76 & 88 & 0.29 \\
\hline Periradicular lesions & 33 & 31 & 45 & 0.3 \\
\hline Gingival pockets $>6$ mm & 36 & 52 & 38 & 0.2 \\
\hline Residual roots & 6 & 33 & 31 & $<0.001$ \\
\hline Professional hygienisation & 48 & 56 & 79 & 0.007 \\
\hline Conservative treatment & 30 & 48 & 40 & 0.18 \\
\hline Surgical treatment & 30 & 52 & 55 & 0.013 \\
\hline Endodontic treatment & 26 & 26 & 20 & 0.7 \\
\hline
\end{tabular}

es their teeth 3 times a day (63\%). The worst situation was in patients who did not brush their teeth regularly. Eighty-three percent of patients had potential foci of inflammation, half required urgent treatment in the field of dentistry and $83 \%$ required urgent surgery (extractions residual roots) (Table 3 ).

Also, the frequency of regular visits to the dental office affects the state of oral hygiene. CPITN index from 0 to 2 most was found in patients visiting dentist once a year or more frequently ( 80 vs 64 vs $50 \%, \mathrm{p}=0.014$ ) (Table 4 ). In patients not brushing their teeth regularly, CPITN index was 3-4. These relationships were statistically significant $(\mathrm{p}=0.014)$.

API index $>70$ was significantly more common in patients visiting their dentist irregularly (69 vs 55 vs $29 \%$, $\mathrm{p}<0.001$ ) (Table 5).

Eighty-eight percent of patients who do not visit the dentist regularly have the potential inflammation foci, $45 \%$ of patients have periradicular lesions and residual roots $31 \%$ (Table 5 ). Statistically significant least residual roots have patients going to the dentist once a year or more often $(6 \%, p=0.001)$. Most patients requiring urgent hygienic procedures $(79 \%, \mathrm{p}=0.007)$ and urgent surgery (55\%) were in the group of patients who did not have regular dental visits.

All data are presented in percentages. 


\section{Discussion}

Oral hygiene status depends mainly on 2 factors: regular teeth cleaning (tooth brushing with fluoride toothpaste, dental floss after eating, toothpicks, interdental brushes, using liquid mouthwash) and the regular attendance for follow-up visits to the dentist.

There are frequently repeated allegations during public discussions such as "visits to the dentist are expensive" and "private health care requires additional funding", but, according to research conducted in 2011 in Poland, only $22 \%$ of patients eligible for dental treatment reimbursment benefit from this option in centers that have signed contracts with the National Health Fund. ${ }^{15}$ Daily teeth cleaning habits are another factor. The price of toothpaste and toothbrushes is not high; the frequency of tooth brushing is not sufficient.

In a study conducted in Poland, in a group of over 600 patients older than 65 years, almost $80 \%$ brush their teeth 1 or 2 times a day. Only 3\% brush their teeth three times a day, and as many as $20 \%$ do not regularly brush their teeth. ${ }^{14}$ However, in a study conducted in 2009, in the United Kingdom, $75 \%$ of patients brush their teeth twice a day or more frequently and only $3 \%$ do not brush their teeth regularly. ${ }^{16}$ In our study, $94 \%$ of patients brush their teeth at least once a day, and only $4 \%$ brush their teeth regularly. The ratio of patients brushing their teeth regularly depends on age. Additional training for older adults in long-term care facilities should be introduced into the everyday practice. ${ }^{17}$

This data is comparable with the data from the Ministry of Health. According to available data, more than $97 \%$ of Małopolska residents brush their teeth once a day or more often. Compared to the data from all of Poland (90\% of people brush their teeth once or twice a day and more than $8 \%$ do not brush regularly), patients in our region take great care of their oral hygiene. ${ }^{18}$

The regularity of brushing teeth has an influence on good oral hygiene status. Among adults aged 35-44 years in Poland, in recent years there has been an increase in the proportion of people with healthy periodontium from $12.7 \%$ in 1998 to $14.1 \%$ in 2002 .

However, in Sweden, the prevalence of moderate periodontal disease fell from $44.8 \%$ to $15.7 \%$ in the overall study population, while the percentage of patients with advanced periodontal disease has remained almost the same in 1983 and 2008 (7.4 and 9.2\%). ${ }^{3}$ In our study, half of the patients regularly brushing their teeth have an index CPITN 3 or 4 . In the group of patients brushing their teeth 3 times a day, only $16 \%$ had CPITN 3 or 4 . It follows that patients who less often brush their teeth have bigger periodontal treatment needs.

The situation is similar when comparing the other parameters of oral hygiene status. Patients brushing their teeth frequently ( 3 times per day or more often) have a better indicator of the API (only 32\% of the API is $>75 \%$ ), fewer patients have pockets greater than $6 \mathrm{~mm}$
(21\%) and this group of patients has the least potential for foci of inflammation in the oral cavity (63\%). Irregular brushing leads to poor oral hygiene status (API > 75 were $85 \%$ and $83 \%$ of patients in this group have the potential foci inflammations in the mouth).

Also the medical needs are evaluated in these groups. In patients not brushing their teeth regularly, half require medical treatment while more than $80 \%$ of the patients required surgical treatment. While those who brush their teeth 3 times daily had significantly less need for maintenance treatment (16 vs 50\%, p = 0.094) and surgical (32 vs $83 \%, \mathrm{p}=0.08$ ). Therefore, the majority of patients who irregularly brush their teeth have infectious foci in the oral cavity, which can affect the development of many systemic diseases. The correlation between oral pathologies and systemic diseases has long been proven. In a study of the English population, $64 \%$ of adults who at least twice a day brushed their teeth have visible bacterial plate compared with $94 \%$ of those patients who confess to teeth brushing at least once a day, or not at all. Men are more likely than women to have plaque (71 vs $61 \%$ ) and also constitute a higher percentage of patients requiring treatment for their teeth (27 vs 20\%). ${ }^{16}$ This is proof that irregular brushing in many cases is not sufficient. The development of lesions in the mouth causes the need for regular visits to the dentist. Data from the Ministry of Health, including more than 2000 patients, showed that in 2010 almost $60 \%$ of respondents visited a dentist at least once in the last year. ${ }^{18}$ In our study, $40 \%$ of patients go to the dentist once a year or more frequently and over a third do not attend regular check-ups. This has an impact on the state of oral hygiene. Half of the patients with CPITN 3 or 4 do not regularly visit a dentist and every fifth examined visits once a year. Patients who do not visit a dentist regularly have frequent apical changes (45 vs 33\%), significantly more residual roots ( 31 vs $6 \%, \mathrm{p}<0.001$ ) and significantly more hygienic require treatment ( 79 vs $48 \%, p=0.007$ ) compared to patients visiting the dentist once a year. In this group, significantly more patients have APIs $>70$ ( $69 \%$ vs $55 \%$ vs $2 \%$ vs $9 \%, \mathrm{p}<0.001$ ) and a greater percentage of patients present potential inflammatory foci (88 vs $77 \%)$ and are significantly more likely to require surgical treatment (55 vs 30 vs $52 \%, \mathrm{p}=0.013$ ). In summary, we conclude that the irregular dental visits cause the deterioration of oral health and a statistically significant increase in the number of patients requiring dental treatment.

In a study of 6,000 patients living in England, in 2009, almost $2 / 3$ (61\%) of adults said that the reason for going to the dentist is a check-up. Twenty-seven percent said they visit only as a result of a toothache. ${ }^{16}$ Adult patients who said they report to the dentist for a check-up visit rarely had visible bacterial plate (61\%) than those who report to the dentist only when pain occurs (76\%).

Oral health is a fundamental component of health and physical and mental well-being; and therefore, great emphasis should be put on proper health habits. ${ }^{19}$ 
Summing up the results of our study, we can conclude that irregular brushing promotes poor oral hygiene and, consequently, increases the need for dental treatment, especially surgical treatment. Patients brushing teeth 3 times a day or more often had the best oral hygiene. Irregular follow-up visits to the dentist also affect the deterioration of oral hygiene. Patients avoiding regular visits have significantly greater medical needs, more often had residual roots, needed surgery and exhibited a greater risk of occurrence odontogenic inflammatory foci. Patients who arrange for follow-up visits at least once a year have lowest amount of potential foci of inflammation and the best oral hygiene.

From an economic point of view, more frequent tooth brushing and regular visits to the dentist reduce the need for dental treatment in subjects, and thus reduce financial spending on dental services for patients.

Therefore, it is important to conduct population-based studies that will determine treatment needs of society and identify the range of the most necessary educational campaigns among patients.

\section{References}

1. Morrison H, Ellison L, Taylor G. Periodontal disease and risk of fatal coronary heart and cerebrovascular diseases. J Cardiovasc Risk. 1999;6:7-11.

2. Lam O, Zhang W, Samaranayake L, Li L, McGrath C. A systematic review of the effectiveness of oral health promotion activities among patients with cardiovascular disease. Int J Cardiol. 2011;151:261-267.

3. Edman K, Ohrn K, Holmlund A, Nordström B, Hedin M, Hellberg D. Comparison of oral status in an adult population 35-75 year of age in the county of Dalarna, Sweden in 1983 and 2008. Swed Dent J. 2012;36:61-70.

4. Krustrup U, Holm-Pedersen P, Petersen P, Lund R, Avlund K. The overtime effect of social position on dental caries experience in a group of old-aged Danes born in 1914. J Public Health Dent. 2008;68:46-52.

5. Petersen P. The World Oral Health Report 2003: Continuous improvement of oral health in the $21^{\text {st }}$ century - the approach of the WHO Global Oral Health Programme. Community Dent Oral Epidemiol. 2003;31:3-23.

6. Hugoson A, Koch G. Thirty year trends in the prevalence and distribution of dental caries in Swedish adults (1973-2003). Swed Dent J. 2008;32:57-67.

7. Petersen $\mathrm{P}$, Ogawa $\mathrm{H}$. Strengthening the prevention of periodontal disease: The WHO approach. J Periodontol. 2005;76:2187-2193.

8. Skudutyte-Rysstad R, Eriksen $\mathrm{H}$, Hansen B. Trends in periodontal health among 35-year-olds in Oslo, 1973-2003. J Clin Periodontol. 2007;34:867-872.

9. Holst D, Schuller A. Oral health changes in an adult Norwegian population: A cohort analytical approach. Community Dent Oral Epidemiol. 2000;28:102-111.

10. Iwanicka-Frankowska E, Wierzbicka M, Szatko F, Pierzynowska E, Zawadziński M. Oral health of the adult Polish population aged 35-44 years old in 1998-2002. Stomatol Wspol. 2003;8(5):9-14 (in Polish).

11. Ziętek M. Oral health of Poles. Czas Stomatol. 2005;58:288-291 (in Polish).

12. Adachi M, Ishihara K, Abe S, Okuda K. Professional oral health care by dental hygienists reduced respiratory infections in elderly persons requiring nursing care. Int J Dent Hyg. 2007;5:69-74.

13. Pyle $M$, Stoller E. Oral health disparities among the elderly: Interdisciplinary challenges for the future. J Dent Educ. 2003;67:1327-1336.
14. Skorupka W, Zurek K, Kokot T, Nowakowska-Zajdel E, Fatyga E, Niedworok E, Muc-Wierzgoń M. Assessment of oral hygiene in adults. Cent Eur J Public Health. 2012;20:233-236.

15. Dostępność i finansowanie opieki stomatologicznej ze środków publicznych. 2011, https://www.nik.gov.pl/plik/id,5280,v,artykul_8390 (in Polish).

16. Hill K, Chadwick B, Freeman R, O'Sullivan I, Murray J. Adult Dental Health Survey 2009: relationships between dental attendance patterns, oral health behavior and the current barriers to dental care. BrDent J. 2013;214:25-32.

17. Kohli R, Nelson S, Ulrich S, Finch T, Hall K, Schwarz E. Dental care practices and oral health training for professional caregivers in long-term care facilities: An interdisciplinary approach to address oral health disparities. Geriatr Nurs. 2017, doi:10.1016/j.gerinurse.2016.11.008.

18. Wyniki badań epidemiologicznych prowadzonych w ramach programu "Monitoring Zdrowia Jamy Ustnej” w 2010 roku. http://www.mz.gov.pl/wwwfiles/ma_struktura/docs/wynik_bada_ mat_26102011 (in Polish).

19. Glick M, Williams DM, Kleinman DV, Vujicic M, Watt RG, Weyant RJ. A new definition for oral health developed by the FDI World Dental Federation opens the door to a universal definition of oral health. Int Dent J. 2016;66:322-324. 